\title{
LA CONSTRUCCIÓN DEL SUJETO FEMENINO EN LAS POESÍAS LÍRICAS DE MARÍA JOSEFA GARCÍA GRANADOS: UNA PIONERA DEL ROMANTICISMO ENTRE DOS MUNDOS
}

\author{
THE CONSTRUCTION OF THE FEMALE SUBJECT IN THE LYRICAL \\ POEMS OF MARÍA JOSEFA GARCÍA GRANADOS: A PIONEER \\ OF THE ROMANTICISM BETWEEN TWO WORLDS
}

\author{
Helena establier Pérez \\ Universidad de Alicante. Alicante, España \\ Helena.Establier@ua.es
}

\begin{abstract}
Resumen: En la década de 1830, y en pleno proceso de adaptación de la literatura romántica en América, una poeta de origen español casi desconocida fuera de los círculos literarios guatemaltecos, María Josefa García Granados, cultiva ya el periodismo, la sátira política en verso y también la poesía lírica. Adelantándose en más de una década a la eclosión de la poesía romántica femenina en España y casi en dos a las escritoras del continente americano, García Granados se convierte en la primera mujer que introduce los temas y las formas de este novedoso movimiento literario a uno y otro lado del Atlántico. En sus poemas líricos, además, aparecen por vez primera las inquietudes y los motivos que configurarán años más tarde el canon de la escritura femenina del Romanticismo. En este trabajo se analizan algunos de estos poemas de María Josefa García Granados, que han pasado hasta el momento desapercibidos tanto para la historia del movimiento romántico como para los estudios centrados en la labor de las escritoras en este período.
\end{abstract}

Palabras clave: María Josefa García Granados, poesía, Romanticismo, escritura de las mujeres, género, sujeto femenino, lírica, Guatemala, España.

\begin{abstract}
In the 1830s, in the process of adaptation of Romantic literature in America, a poet born in Spain and almost unknown outside Guatemalan literary circles, María Josefa García Granados, was already cultivating journalism, political satire in verse and also lyric poetry. Anticipating by more than a decade the appearance of Romantic feminine poetry in Spain and by almost twenty years the activity of American women writers, García Granados becomes the first woman to introduce the topics and the forms of this new literary movement on both sides of the Atlantic Ocean. The
\end{abstract}


concerns and the subjects that will much later shape the canon of Romantic women's writing appear for the first time in her lyric poems. This paper discusses some poems of María Josefa García Granados so far unnoticed both by the history of the Romanticism and by studies focusing on the work of women writers in this period.

Keywords: María Josefa García Granados, poetry, Romanticism, women writing, gender, female subject, lyric, Guatemala, Spain.

Recibido: 08.02.2015. Aceptado: 30.07.2015.

$\mathrm{L}$ A Difusión DE LOS TEMAS y las formas del Romanticismo en América se inicia, como ya sabemos, en los albores de la tercera década del siglo XIX, al calor de las independencias coloniales y de las efervescentes relaciones culturales entre lo más granado de la intelectualidad hispanoamericana y la Inglaterra de Wordsworth, Coleridge o Byron ${ }^{1}$, cuyos poemas, junto con las reflexiones teóricas del historicismo alemán desarrolladas a partir de J. G. Herder y a los modelos aportados por la poesía francesa especialmente la de Víctor Hugo-, constituyen los textos incitadores del Romanticismo americano (Barreda y Béjar, 1999, p. 5). De hecho, antes de 1830, adelantándose casi en una década a la cronología oficial del movimiento en España, ya se perciben los aires románticos en las letras de este continente, de forma que aunque el espaldarazo definitivo, de la mano de las Poesías del cubano José María Heredia, llegue en 1825, durante esos años varios jóvenes poetas - como el venezolano Antonio Ros de Olano, el mejicano Fernando Calderón o el colombiano Luis Vargas Tejada- muestran ya en sus obras una simbiosis evidente de formas neoclásicas y modos románticos (Rivera-Rodas, 1988, pp. 14-15)².

La presencia femenina en las filas de esta precoz oleada americana de poetas románticos, que no constituyen aún en estas décadas tempranas

${ }^{1}$ El estudio de P. Grases sobre Andrés Bello en Londres (1962), muestra la presencia de un nutrido grupo de jóvenes intelectuales y escritores americanos en la Inglaterra de las primeras décadas del siglo y, por ende, certifica el trasvase de principios románticos entre el viejo y el nuevo continente.

${ }^{2}$ Con contundencia desmonta Rivera-Rodas en su estudio sobre la poesía hispanoamericana del XIX (1988) las ideas establecidas por ciertos trabajos clásicos (el de E. Carilla, por ejemplo, de 1967) acerca de una cronología paralela entre el romanticismo español y el hispanoamericano, y de una influencia "originaria" del primero sobre el segundo. 
del XIX ni escuela oficial ni movimiento literario organizado, es casi absolutamente inexistente. De hecho, a excepción de la propia María Josefa García Granados ${ }^{3}$, las escasas mujeres que escriben en la América recién independizada lo hacen en torno al medio siglo, al amparo de la eclosión y de la difusión del Romanticismo, como la boliviana María Josefa Mujía (1811-1888), la ecuatoriana Dolores Veintimilla de Galindo (1829-1857), la cubana Luisa Pérez de Zambrana (1835?-1922) o las guatemaltecas Jesús Laparra de la Cerda (1820-1887), Vicenta Laparra de la Cerda (1831-1905) y Josefa Córdova y Aragón (1838-?).

En Guatemala, patria adoptiva de María Josefa García Granados, a pesar de las limitaciones culturales propias de las décadas que siguen a la Independencia (1821), reflejo fiel en lo literario del desolador panorama socioeconómico del período colonial (Liano, 1984, p. 65; Vela, 1943, p. 153), el Romanticismo había ya encontrado en esos años vías de expresión propias, en convivencia estrecha con las últimas muestras de las tendencias ilustradas. El de José Batres Montúfar (1809-1844) es sin lugar a dudas el nombre más destacado de las letras guatemaltecas durante más de dos décadas, pero junto al suyo brillan también los de José de Irisarri (1786-1868), Francisco Rivera Maestre, Juan Diéguez Olaverri (1813-1866) y el de la propia María Josefa García Granados (1796-1848), recogidos todos ellos, como no podía ser de otra manera, en el Parnaso guatemalteco (1750-1928) de Humberto Porta Mencos4.

Por aquellos años, ni era factible en América la posibilidad de una "hermandad lírica femenina” al estilo de las románticas españolas ${ }^{5}$, susceptible

${ }^{3}$ Y de Gómez de Avellaneda, evidentemente, aunque su carrera literaria se desarrolla en España, donde en 1841 publica su primer volumen de Poesías. Este y el libro del mismo título de Josefa Massanés, constituyen las primeras manifestaciones con resonancia pública de las "poetisas" románticas en la Península.

${ }^{4}$ Junto a estos nombres, Porta Mencos recoge también otros ya algo posteriores como Domingo Estrada (1851-1901), Juan Fermín Aycinena (1838-1898) e Ismael Cerna ( $\dot{c}-1901)$.

${ }^{5}$ En España, aunque el movimiento romántico femenino se había iniciado en 1841 -fecha en que, como hemos señalado más arriba, Gertrudis Gómez de Avellaneda y Josefa Massanés publican sus primeros libros de poesía-, el pistoletazo de salida lo da Carolina Coronado con la publicación de sus Poesías prologadas por Hartzenbusch en 1843. A partir de este momento, los principales temas, motivos e imágenes de la poesía romántica femenina serán mimetizados o reinterpretados por sus "discípulas" (Vicenta García Miranda, Encarnación Calero de los Ríos, Robustiana Armiño, Amalia 
de estimular unos cauces y unos modos poéticos comunes, ni detectamos tampoco la presencia de una "escuela" romántica guatemalteca en la que la autora pudiera -quizá- haberse incardinado pese a las limitaciones impuestas por su género. En estas circunstancias, María Josefa García Granados se convierte simultáneamente en la única escritora de la Guatemala de su tiempo y en la primera mujer poeta de la América poscolonial. Veremos a continuación cómo esta solitaria lira femenina en un mundo poético de hombres, guatemalense de sangre y cuna españolas, se atrevía, con una década de antelación respecto a sus compañeras de uno y otro lado del Atlántico, a traducir a Byron, a hacer política a través de la poesía, a escandalizar a la sociedad de su tiempo con versos jocosos de explícito contenido sexual y -sobre todo- a trasladar el novedoso sujeto femenino romántico a la recién nacida lírica poscolonial.

\section{Una española en Guatemala}

No es, desde luego, tarea fácil seguir las huellas de María Josefa García Granados. Los estudios sobre el Romanticismo español la ignoran absolutamente $^{6}$, pese a que la escritora, oriunda del Puerto de Santa María (Cádiz), pisó tierra americana por vez primera a la edad de catorce años, en 1811, y mantuvo firmes lazos sentimentales y poéticos con la Península (Establier, 2015). Desconcertante resulta también el desinterés que los estudios de la crítica hispanoamericana -exceptuando los trabajos más locales- han mostrado hacia su obra si consideramos que el "ruiseñor de los estudiantes" -así la llamaron por tierras guatemaltecas- ostenta el mérito de ser, tal como hemos señalado, la primera mujer que cultivó el Romanticismo en el ámbito hispanoamericano. De hecho, la autora no aparece citada -ni recogida su obra- en los principales estudios o antologías de poesía hispa-

Fenollosa, etc.), que constituyen una suerte de grupo poético con relaciones mutuas, líricas y epistolares, bautizado por Antonio Manzano como "hermandad lírica" (1969, p. 7), etiqueta que ha alcanzado cierta fortuna en el ámbito crítico.

${ }^{6}$ Sí la nombra de pasada, como "poetisa española”, Menéndez Pelayo en su Historia de la poesía hispanoamericana (1948, p. 187). 
noamericana decimonónica (Carilla, 1967; Rivera-Rodas, 1988; De Vallejo, 1993; Barreda y Béjar, 1999).

La crítica de Guatemala sido bastante más generosa con la escritora, a la que, pese a su origen español, no ha dudado en hacer suya y en señalar como una de las más insignes poetisas guatemaltecas ${ }^{7}$. No en vano es el de García Granados el primer nombre femenino asociado al cultivo de la poesía en Guatemala tras el de Sor Juana de Maldonado (1598-1666), y quizá por ello, desde el último cuarto del XIX hasta 1950 aparece su obra ya citada en algunos trabajos y antologías del ámbito centroamericano (Batres Jáuregui, 1879; Uriarte, 2009; Porta Mencos, 1928) y también es objeto de diversos artículos en la prensa guatemalteca (Mencos Franco, 1899-1900; Díaz, 1932; Brañas, 1948). Esta tímida recuperación de la obra de García Granados, dispersa aún entonces en las hemerotecas guatemaltecas ${ }^{8}$, culmina en 1971 cuando Jorge Luis Villacorta reúne los poemas conservados de García Granados y algunos fragmentos de los textos publicados sobre ella en una antología que es, actualmente, el punto de partida inevitable de cualquier trabajo sobre la autora.

Desde entonces, García Granados se ha vuelto imprescindible en los compendios y estudios de la literatura guatemalteca y centroamericana (Figueroa y Acuña, 1977; Albizúrez y Barrios, 1981; Méndez de la Vega, 2002; Gallegos Valdés, 1984; Hoeg, 2004; Salgado, 2004; Ávila, 2004; López, 2009), aunque su eco fuera del ámbito centroamericano siga siendo prácticamente nulo9.

Los escasos datos familiares que conservamos sobre la escritora, cono-

${ }^{7}$ De ella y de su hermano, Miguel García Granados, dice el estudioso guatemalteco Horacio Figueroa que eran "españoles de nacimiento, pero guatemaltecos por el corazón, la raigambre y porque aquí quemaron su vida y dejaron sus restos" (Villacorta, 1971, p. 171).

${ }^{8}$ Diez poemas de la autora fueron publicados por la revista El Museo Guatemalteco entre julio y diciembre de 1858 , en homenaje al décimo aniversario de su fallecimiento.

${ }^{9}$ En 2010, la colección "Clásicos de la Literatura Guatemalteca" de la Tipografía Nacional de Guatemala realiza una nueva edición de su obra basada en la de Villacorta, y añade, en sus anexos, unas epístolas entre la escritora y su íntimo amigo, el poeta José Batres, recogidas por Arzú en su Pepe Batres íntimo (1940). Esta antología de Enrique Noriega, por la que citaremos en el presente trabajo la obra de la autora, incluye también su único retrato conservado, cedido por los descendientes para dicha edición. 
cida generalmente con el nombre de "la Pepita" (Montúfar, 1898, p. 34) provienen de las memorias de su hermano menor, el militar y político Miguel García Granados ${ }^{10}$, y de la reconstrucción biográfica que es posible pergeñar a partir de la inestimable antología realizada por Villacorta.

$M^{a}$ Josefa García Granados nació el 10 de julio de 1796 en el Puerto de Santa María, tierra de su padre. Cuatro años antes, don José García Granados había regresado de Guatemala, donde se había labrado una considerable fortuna con la venta de diferentes mercaderías llevadas desde Cádiz, y donde, de paso, había contraído compromiso de matrimonio con María Gertrudis Zavala, hija de una familia de gran linaje y no menos posibilidades económicas, que emigró a la Península un año después de la vuelta de don José, en 1793, y casó a su hija con el comerciante español. Según relata Miguel García Granados, el asedio francés a Cádiz en 1810 empujó a su padre a marchar a Guatemala, donde aún conservaba intereses. En la capital guatemalteca se estableció la familia García Granados en 1811 (García Granados, 1952, I, p. 6), allí falleció la madre en 1816, dejando once hijos vivos, y allí también contrajo matrimonio dos años más tarde María Josefa con el nicaragüense Ramón Saborío ${ }^{11}$.

Apenas un año después de jurar la Constitución española, el 15 de septiembre de 1821, la Capitanía General de Guatemala se separó de la metrópoli y tres años más tarde se constituyó la República Federal de Centroamérica y se promulgó la constitución federal, que, teñida del pensamiento liberal de la época, trataba de consolidar los intereses políticos de los grupos progresistas y de quebrar el poder de la oligarquía dominante.

Desde entonces, el bienestar del que había gozado la familia García Granados en América gracias al comercio que mantenían los hermanos mayores con Belice se vio considerablemente mermado ${ }^{12}$. Hacia 1827, los

${ }^{10}$ Miguel García Granados fue un conocido militar y político, cabecilla de la Revolución Liberal de Guatemala de 1871 y Presidente del país entre ese año y 1873.

${ }^{11} \mathrm{El}$ acta de matrimonio la reproduce Villacorta (1971, p. 241).

${ }^{12}$ Por un lado, graves discordias internas amenazaban a la joven federación, cuyos miembros rechazaban a la élite comercial y burocrática guatemalteca, que había ejercido el poder durante la época colonial y que controlaba tanto la administración del Estado como el comercio interior y exterior; por otro, la clase alta guatemalteca se hallaba también dividida entre liberales o federalistas (criollos progresistas en su mayoría) y conservadores o centralistas (en gran parte, miembros de la oligarquía peninsular y de las familias guatemaltecas con títulos nobiliarios). 
conservadores habían tomado el poder tanto del gobierno de Guatemala como del federal, pero en 1829 el ejército liberal comandado por el general hondureño Francisco Morazán tomó la ciudad de Guatemala. En agosto de ese año, el gobierno del Estado de Guatemala confiscó la tercera parte de la fortuna de todos aquellos que habían colaborado con el régimen anterior, medida que afectó considerablemente a la familia García Granados, que vio cómo sus almacenes y mercancías se ofrecían en pública subasta por un precio irrisorio. Bajo la presidencia de Morazán (1830-1840), se sucedieron las reformas liberales en la federación, implementadas en Guatemala por Mariano Gálvez, elegido Jefe de Estado en 1831: limitación del poder del clero, expropiación de sus bienes, ley del divorcio, libertad de cultos, reforma educativa y judicial, etc.

En este ambiente revuelto, María Josefa fue creciendo como mujer y como poeta. Su hermano Miguel la recuerda como "mujer de genio independiente, despreocupada, de mucho ingenio y travesura; con gran facilidad para versificar y mucho chiste en sus sátiras; era lo que puede llamarse un ente original y de trato peligroso. iPobre de aquel a quien le ponía la puntería!” (1952, II, p. 307). El retrato de María Josefa que nos deja el general en sus memorias es bastante sorprendente y refleja a una mujer inusual, admitida en las reuniones de varones por gozar de "alguna nombradía por su ingenio y carácter original” (1952, II, p. 305), valiente y provocadora, fugitiva de la justicia en tiempos de Morazán (1952, II, pp. 307-8), culta, alegre y un tanto neurasténica (1952, II, p. 309).

José Martí, por su parte, pionero en la reivindicación literaria de Josefa García Granados, la dibuja en su ensayo Guatemala ${ }^{13}$ como una mujer versátil y polémica ("talento penetrante, alma ardiente, rima facilísima, espíritu entusiasta, carácter batallador, [...] por mucho tiempo animación y para siempre gala de la literatura guatemalteca”, 2007 [1913], pp. 84-85), aunque un tanto excesiva ("abundante, tanto en pensamiento como en versos”, 2007 [1913], p. 85).

Más allá de este mito de la poetisa-amazona histérica y romántica, fabricado a partir de los escasos testimonios que nos han quedado, la vida

${ }^{13}$ José Martí pasó en Guatemala varios meses en 1877 y el resultado de su estancia es el interesantísimo ensayo titulado Guatemala, publicado inicialmente como folleto en 1878, en el que dedica tres páginas a María Josefa García Granados. 
privada de García Granados es casi una incógnita. Sabemos que en los años veinte ya asistía de forma regular a las "tertulias patrióticas" del canónigo español, prócer de la independencia guatemalteca, José María Castilla (García Granados, 1952: III, p. 363), donde tenía a su disposición una magnífica biblioteca en la que no escaseaban los textos de los librepensadores dieciochescos franceses.

Sabemos también, a través de los propios escritos de "la Pepita", que en los años treinta, a resultas de los estragos sufridos por su familia en la ofensiva federalista, era enemiga acérrima de los políticos liberales, a quienes ridiculizaba en unos retratos poéticos en verso que le valieron, tal y como hemos señalado más arriba, la persecución y el autoexilio ${ }^{14}$, y que aprovechaba cualquier excusa para ridiculizar con sus sátiras en verso las actuaciones de sus oponentes ${ }^{15}$.

Gracias a los estudios de Arzú, especialista en la poesía de José Batres Montúfar, sabemos de la íntima amistad que unió a ambos hasta la muerte del escritor, en 1844. Juntos fundaron el periódico Cien Veces Una, en contestación a otro llamado Diez Veces Diez, publicado por algunos liberales guatemaltecos en la República de El Salvador. Huelga decir que en los años en que García Granados asaeteaba a sus contrincantes liberales desde las páginas del Cien Veces Una, es decir, a mediados de la década de 1830, la presencia femenina en el mundo de la prensa -y aún más de la política- era aún inimaginable, y seguramente un tanto escandalosa. Con Batres compuso también el célebre sermón dedicado al canónigo Castilla, obra que califica Ramón Salazar en sus memorias como "pieza pornográfica, llena de ingenio y sal, no tiene parecidas, sino en algunas de igual género atribuidas a Espronceda" (1896, p. 103) y, según Mencos Franco, juntos iniciaron el desaparecido periódico La aurora (Villacorta, 1971, p. 53).

Amiga por igual de liberales y conservadores, incluso de algunos a los que lapidó con sus versos, se opuso con virulencia a quienes en nombre del

${ }^{14}$ En 1830 la autora se refugió en la antigua Ciudad Real (México) durante unos meses hasta que las aguas se calmaran.

${ }^{15}$ De hecho, a raíz de la gravísima epidemia de cólera que sufrió Guatemala en 1837, la escritora difundió un "Boletín del cólera morbus" -publicado después, en 1858, por el periódico El Museo Guatemalteco-, donde en verso y en forma dramática se burlaba abiertamente de la pésima actuación de los especialistas a los que el gabinete de Mariano Gálvez había encargado el tratamiento de la enfermedad. 
nuevo estado federal y de una Guatemala independiente acosaron y arrinconaron a la vieja oligarquía colonial, y pese a su conservadurismo político, fue, en todo lo demás, una librepensadora convencida. Apenas ningún dato más de relevancia nos queda de la vida de María Josefa García Granados, concluida en 1848, unos meses después de la fundación de la República de Guatemala bajo el régimen conservador de Carrera.

\section{Versos románticos y nuevo sujeto poético femenino}

La obra conservada de Pepita García Granados, aunque breve, puede articularse en dos bloques, dos grupos de composiciones que responden -creo- a dos concepciones distintas de la creación poética y a dos facetas complementarias de una personalidad compleja, aunque a un mismo espíritu literario, el romántico. Contamos, por un lado, con una serie de versos de tipo satírico, jocoso o burlesco, destinados a expresar el descontento ante la política del partido liberal, a ridiculizar públicamente a sus dirigentes, o a provocar a la sociedad de su tiempo burlándose abiertamente de ciertas actitudes y costumbres ${ }^{16}$ : diversos retratos de políticos, el "Sermón” dedicado al canónigo Castilla, el "Boletín del cólera morbus" y las composiciones varias publicadas en el periódico Cien Veces Una. Por otro lado, destaca un

${ }^{16}$ En lo que respecta al primer grupo de composiciones señaladas, recordemos que la sátira, de raíz ilustrada, es una de las formas más consolidadas de expresión romántica, que en América se canaliza a través de la parodia descarnada de los sistemas políticos generados tras el proceso independizador y de la manifestación de las rivalidades entre los defensores de las diferentes opciones gubernamentales (Vela, 1943, p. 157). La sátira estuvo absolutamente arraigada en la prensa americana del período, como manifestación culta pero también como expresión de la cultura popular, a través de letrillas, canciones patrióticas, fábulas políticas, epigramas contra políticos y partidos, parodias, himnos burlescos, etc., siempre centrados en asuntos de interés local y a veces impregnados de auténtica virulencia:

El equilibrio muy especial entre la corriente culta y la corriente popular en los textos conservados, la omnipresencia de las rivalidades políticas hasta en los textos de ficción y el papel preponderante del pueblo hacen que muchas veces la sonrisa esté reemplazada por explosiones de risa y que estas risotadas se relacionen menos con las carcajadas suscitadas por algún aspecto ridículo que nos divierte o con la risa carnavalesca y ambivalente descrita por Bajtin cuando explicaba lo cómico en Rabelais, que con el odio, con la agresividad, la crueldad (Wentzlaff-Eggebert, 1995, p. 238). 
reducido núcleo de doce poemas íntimos, algunos incluso en clave, repletos de motivos personales, pero también de sentimientos, de angustias y de temores de alcance universal: "Descripción de la erupción del Cosigüina", "A la ceiba de Amatitlán”, "A una hermosa joven”, “A un amigo", "A una abeja”, "A la esperanza”, "Despedida”, "Plegaria”, "La resolución”, "Himno a la luna”, "Dedicatoria del himno precedente, a Don Á. Saavedra” y la traducción de la "Canción de Medora".

Las composiciones burlescas y satíricas de García Granados, que nos dibujan el perfil de una escritora mordaz, autosuficiente, valiente, divertida, incisiva, conforman la parte de su obra que mejor conocieron sus coetáneos y que pervivió en las generaciones inmediatamente posteriores ${ }^{17}$. Sin embargo, el "localismo", que impregna sus versos jocosos, ligados a los personajes y a las circunstancias que los provocaron, es posiblemente la causa de que, aun cuando estas sigan siendo una buena muestra de esa vía satíricoburlesca que caracteriza parcialmente las letras románticas, hayan perdido actualidad y su objetivo nos quede hoy un tanto desdibujado ${ }^{18}$.

Mientras tanto, los poemas líricos de la autora, aquellos en los que se vuelca entera con la fuerza del sentir romántico, son también, como las propias emociones que los inspiran, más resistentes al paso del tiempo. De hecho, por debajo de la imagen pública y un tanto alocada que transmiten los versos satíricos, estos otros destilan una gran sensibilidad y, tocando con acierto las cuerdas de la lira romántica, nos desvelan un alma atormentada que no coincide con el retrato habitual de la incisiva Pepita García Granados, el "ruiseñor de los estudiantes".

Me centraré aquí pues en esta parte más lírica de la obra de García Granados, menos valorada por las generaciones inmediatamente posteriores,

${ }^{17}$ Buen reflejo de ello es la admiración mostrada por José Martí en el ensayo anteriormente citado, Guatemala, hacia los versos de García Granados, de los cuales, nos dice, no valía tanto lo serio como lo incisivo (2007 [1913], p. 85).

${ }^{18}$ Observo, no sin cierta sorpresa, que esta parte de la obra de la autora sigue siendo aún hoy la más celebrada por quienes se han acercado a ella. Fue, de hecho, el objeto de una Tesis de Graduación dirigida por Francisco Albizúrez (Torres Valenzuela, 1989), coautor de la Historia de la literatura guatemalteca (1981), en la cual se incide también con especial interés en la vena satírica de la escritora. Relaciono este interés con el hecho de que la recuperación de la obra de esta escritora se haya producido hasta el momento únicamente desde los propios círculos críticos guatemaltecos, para los cuales constituye una pieza inestimable en la actualización de la memoria histórica de la Independencia. 
que seguramente buscaban en los versos de la escritora claves para entender su pasado más reciente, e incluso en ocasiones por las actuales ${ }^{19}$, pero sin duda aquella en la que mejor se observa la novedosa construcción del sujeto femenino en la recién nacida poesía romántica.

De hecho, destaca poderosamente en estos poemas impregnados de tópicos románticos la presencia de un sujeto femenino que, consciente de su especificidad de género, dialoga claramente con los modos poéticos al uso. Buen ejemplo de ello son "A una hermosa joven. Desgraciadamente enlazada con un achacoso viejo" y "A una abeja, que no libe la rosa cuyo árbol regaba una mano vil", donde la autora da cauce poético a una inquietud habitual en las poetas románticas, la indefensión amoroso-sexual de las mujeres, y se rebela abiertamente contra ella desplegando la imaginería "natural" cultivada por la lírica femenina.

Así, el soneto “A una hermosa joven” satiriza el asunto de los matrimonios de edad desigual a partir de las metáforas florales de velado contenido sexual que tanto entusiasmaron a las románticas: la joven hermosa es "tierna rosa", de "fragancia deliciosa" y "néctar agradable", que se marchita al abrir su "cáliz lastimado" al "escarabajo sucio y despreciable", de "fetidez insoportable", que habita en su seno ("el achacoso viejo" del título del poema). La imagen metafórica de la hermosa joven/rosa, expuesta a la lubricidad del viejo/escarabajo, alcanza en el soneto calidad de símbolo y se convierte en extensión poética del trágico destino sexual, contra natura, de todo un género: "Tu destino fatal Natura llora/ Pues la flor más brillante se marchita/ Cuando el insecto vil su seno habita” (Noriega, 2010, p. 36).

En "A una abeja”, sin embargo, la simbología femenina se desplaza al insecto, que ya no es un escarabajo repulsivo y pestilente, sino una incauta abeja que, atraída por el hermoso colorido y el engañoso aroma de la rosa, se arriesga a libar de su cáliz un jugo venenoso vertido por maligna mano. Es así, mediante la imagen de la "sustancia sabrosa" de la flor, transformada inopinadamente en veneno letal para la inocente y confiada abeja, como la autora previene a las mujeres de los riesgos de la excesiva ingenuidad en el plano amoroso-sexual:

${ }^{19}$ Ver, por ejemplo, Carrera, 1984, pp. 140-141. 
¿Cómo incauta te atreves, Con riesgo de tu vida, A libar en sus hojas La ponzoña escondida?

Huye su olor fragante Y su vista engañosa. ¡Ay! Huye triste abeja De esa pérfida rosa.

(Noriega, 2010, pp. 39-40)

La naturaleza como tópico romántico y como proyección del yo lírico femenino aparece también en otros dos poemas ("A la ceiba de Amatitlán” y "Descripción de la erupción del Cosigüina”), donde la autora demuestra que su aprendizaje poético, de la mano de algunos maestros del viejo continente (Establier, 2015), ha cristalizado en la expresión propia del romanticismo americano; así, lejos del exotismo y de la idealización con que los europeos venían reflejando el paisaje americano desde el siglo anterior, García Granados nos describe en estos poemas una experiencia directa, sentida -y también femenina- del mismo.

En romance heptasílabo canta la autora "A la ceiba de Amatitlán”; árbol sagrado de los mayas, para quienes representaba la comunicación humana con el cielo y el inframundo, y actualmente árbol nacional guatemalteco, la ceiba posee en su proyección histórica una gran carga simbólica como muestra de la permanencia y solidez de las raíces centroamericanas. Para María Josefa García Granados, además, el ejemplar situado en la plaza de Amatitlán desprendía multitud de connotaciones sentimentales, ya que al parecer fue ella misma quien se encargó de su siembra (Villacorta, 1971: 97). La ceiba de este poema se convierte, de hecho, en una extensión del propio yo poético de la autora: constituye su vínculo con la tierra-madre y con los recuerdos a ella ligados, es símbolo del amor y también lugar privilegiado para el reposo eterno:

Mas bien, árbol querido, Donde el amor reposa, Que al corazón le hablas En lengua misteriosa; 
Si unido a mis recuerdos,
Por ellos simpatizas
Conmigo, que tu sombra
Dé abrigo a mis cenizas.

(Noriega, 2010, p. 51)

La ceiba, esencia de lo femenino, ostenta belleza y solidez, resistencia ante los envites del huracán y del rayo, y solo la mano del hombre, "destructor e ignorante" parece representar una posible amenaza para su pervivencia. El poema, en versos romanceados, destila paz interior, voluntad de permanencia y supervivencia, de fusión con la ceiba-tierra incluso más allá de la vida:

\author{
Que sus lágrimas rieguen \\ Tu raíz carcomida \\ Y mi espíritu y ellas \\ Te den eterna vida
}

(Noriega, 2010, pp. 50-51)

Pero como ya hemos visto en composiciones anteriores, los símbolos de lo femenino que pueblan el imaginario poético de García Granados están expuestos al sufrimiento y a la destrucción. Así, la amenaza solo intuida en "A la ceiba de Amatitlán" se materializa en "Descripción de la erupción del Cosigüina”, oda heroica escrita después de la explosión del volcán nicaragüense en 1835, en la que la autora describe en sextetos alirados el espectáculo "grandioso/Sublime y pavoroso" (Noriega, 2010, p. 25) que ofrece el Cosigüina en erupción. El paisaje que se ofrece a la vista no puede estar más impregnado de motivos románticos: en una especie de noche eterna, donde solo se oye el retumbar del trueno, llueve arena, azufre y ceniza, los habitantes y las fieras corren despavoridos, la lava ardiente, por un lado, y el océano, por el otro, lo inundan todo y dejan a su paso cadáveres, epidemias, desolación, caos... Esa naturaleza embravecida y convulsa por el efecto de la fuerza volcánica lo arrasa todo, hasta los propios símbolos americanos -y femeninos- como la Ceiba, que, perdidos su orgullo y su majestuosidad, yace ahora semienterrada, abatida por la fuerza volcánica. Por supuesto, la desolación externa encuentra su correlato en el alma de la autora, que ya no está armónicamente fundida con la naturaleza sino que se rebela titánicamente contra el horror: 
¡Ah!, no más, basta ya: tantos horrores

Llenan mi corazón de angustia y duelo

(Noriega, 2010, p. 30)

Incapaz de alcanzar la riqueza descriptiva de los maestros ("iOh, quién de Apeles el pincel tuviera,/ O de Byron la pluma deliciosa!”, Noriega, 2010, p. 25), García Granados recurre al tópico femenino de la "captatio benevolentiae" para lamentarse de las limitaciones de su "débil mano" a la hora de pintarle a ese "Alberto", poeta y destinatario de su epístola, el espectáculo que se revela ante sus ojos: "Volcánica explosión y sus efectos/ Bosquejaré con rasgos imperfectos” (2010, p. 25). Las metáforas sexuales se hacen de nuevo evidentes: el volcán, símbolo de la fuerza masculina y de su capacidad de destrucción, frente a la ceiba, esencia femenina y también encarnación natural del yo lírico de la autora, que resulta arrasada y aniquilada por aquel. Estas imágenes, recursos fundamentales en el juego poético de revelación/ocultamiento de la intimidad emocional de las escritoras románticas, dejan las puertas abiertas a una lectura de estos versos en clave sentimental y nos desvelan el sufrimiento amoroso de ese yo femenino aniquilado por una pasión volcánica e imparable.

Esta lectura, en clave pasional, se hace aún más evidente en los tres poemas que incluimos en el que denominamos "ciclo amoroso" de la lírica de García Granados: "Plegaria”, "La resolución” y "Despedida”. Los tres muestran un sujeto poético desbordado por el dolor y la angustia, que prescinde abiertamente del consuelo religioso -tópico habitual en la poesía femenina romántica ${ }^{20}$ - y en su lugar se sirve de la propia creación poética como estrategia para burlar la disgregación interior a la que parece irreversiblemente abocado.

El primero de los poemas señalados, "Plegaria”, recoge en cuatro octavillas agudas el momento de la decepción amorosa, el abandono masculino y la ruptura sentimental; el estado anímico del sujeto poético se transmite a través de las conocidas imágenes románticas de angustia, muerte y oscuridad "(penas”, "dolor”, "temor”, "negros presentimientos”, "funesta reali-

${ }^{20}$ Véanse, por ejemplo, "Entrada en Jerusalén” de Luisa Pérez de Zambrana, "La existencia de Dios" de Jesús Laparra y, en general, los poemas del Devocionario de Gertrudis Gómez de Avellaneda. 
dad", llanto del amado que riega el "sepulcro frío" de la autora, etc.), que encuentran su correlato externo en una naturaleza embravecida y aterradora ("viento horroroso", "huracán tremendo"), marco privilegiado para el "yo" femenino victimizado por un destino amoroso aciago. Nada hay de contenido religioso en la "plegaria" que da título al poema, cuyas destinatarias son la madre de la autora y la virtud; de hecho, ambas funcionan como boyas de flotación del sujeto poético ante la angustia del desamor, como alternativas "femeninas" al consuelo de Dios para evitar la disolución del yo romántico en el dolor.

Las motivaciones y las consecuencias de este "funesto amor" se observan en el poema "La resolución", donde la autora interpela al ya conocido "Fabio" para exponerle su reciente reincorporación al camino de la virtud y de la paz del alma, y también al Amor, para hacerlo responsable de la pesada cadena pasional de la que ahora ya se siente por fin liberada. El tono de esta composición, en décimas espinelas de pie quebrado, es mucho más sosegado que el de la anterior, y anticipa ya el de algunos poemas posteriores de Gómez de Avellaneda como "Amor y orgullo" (1847). El momento de la "loca pasión" amorosa se contempla ya como un sueño, como una "terrible herida" que la inconsecuencia de Fabio ha logrado llegar a cerrar. Los fundamentos de tan "necio error" por parte de la autora se encuentran en la llamarada del amor carnal ("Era tal el ciego ardor/ Que abrasaba el alma mía," 2010, p. 47), una pasión exaltada que conduce al sujeto poético femenino a la locura ("Mi demencia/ Reconozco avergonzada", 2010, p. 47), a la destrucción ("Mi horrible naufragio/ en fiera tormenta", 2010, p. 47) e incluso a actitudes titánicas, en el más puro estilo romántico ("Al cielo osé amenazar,/ Si no me dejaba contigo expirar/ de amor consumidos en llama ferviente”, 2010, p. 48), y que se expresa con una retórica inflamada, en ocasiones discordante con nuestras expectativas de la poesía femenina de la época ${ }^{21}$. En este caso, el desenlace poético supone la reconducción del propio yo hacia la estabilidad emocional:

${ }^{21}$ La espiritualidad y la contención amorosa generalmente atribuidas a la lírica de las románticas forman parte del mito de la "poetisa", que solo parcialmente refleja el auténtico sentir que emana de los versos de estas autoras. De hecho, idéntica retórica amorosa y exaltación pasional a las mostradas por García Granados encontramos en versos posteriores de otras románticas, como Gertrudis Gómez de Avellaneda ("A él”), Ma Josefa Massanés (“Amor”), Dolores Cabrera ("Un pensamiento") e incluso la comedida Ángela Grassi ("Fantasía”, "Sin esperanza”). 
De ese delirio horroroso

iLibre al fin respira el alma!

Y ya nunca más su calma

Podrá turbar, el costoso

Y oprobioso Amor, de que fue cautiva

(Noriega, 2010, p. 48)

Concluiremos haciendo referencia al poema "Despedida”, que encaja a la perfección en el tono elegíaco característico del Romanticismo americano (Rivera-Rodas, 1988, p. 81). Se trata de un adiós a la vida en toda regla, que incluye, como bien señala Rivera-Rodas para la elegía romántica (1988, p. 81), la renuncia de la autora a la propia capacidad de creación: "Bajo el sauce, que sombra nos daba/ He colgado mi fúnebre lira”. La destinataria de esta despedida, rebosante de emotividad, es una "amiga adorada”, unida al yo lírico por unos sentimientos profundos donde caben en idéntica proporción la pasión y la ternura:

Una lágrima sola es bastante

A premiar de mi amor la ternura:

No me impongas la horrible tortura

De adorarte, perderte y vivir.

[...] Moriré con mis labios ardientes

Estrechando tu imagen amante,

Y exclamando con voz espirante:

iAy, Dios, ya no la veré más!

(Noriega, 2010, p. 44)

Sorprende sin duda en el repertorio lírico de García Granados esta composición, cuyo tono de exaltación pasional en octavas agudas encaja a la perfección en el "ciclo amoroso" de "Plegaria" o "La resolución”, pero cuya destinataria resulta ser una mujer. No podemos descartar la posibilidad de que en este poema, y de forma excepcional -ya que habitualmente su obra deja fluir sin ocultaciones ni disimulación la voz femenina-, García Granados asumiera un yo lírico masculino, quizá porque la composición fuera un presente para un amigo o familiar, o por ser un poema primerizo en el que aún experimentara la escritora ciertas -y comprensibles- vacilaciones a la hora de asumir la expresión de un sujeto poético femenino que era absolu- 
tamente novedoso en la lírica de su tiempo. Si esto no fuera así y se tratara, como todo parece apuntar, de un poema donde prevalece la expresión del sentimiento entre mujeres, solo nos quedaría por certificar que, desde el ámbito americano, García Granados se adelanta una vez más y esboza ya un tópico que va a ser habitual años después en las poetas románticas peninsulares: la manifestación de amistad femenina mediante el uso de la retórica amorosa propia de la poesía “erótica” masculina (Mayoral, 1993).

Tal y como hemos visto, la lírica de María Josefa García Granados, pese a constituir un corpus limitado, es una valiosa muestra del incipiente quehacer femenino en la poesía romántica a lo largo de la tercera década del siglo XIX, así como de la proximidad estética entre dos continentes animados por circunstancias socio-políticas dispares. García Granados, como José María Heredia, Ros de Olano, Esteban Echevarría, José Batres Montúfar, etc., mira hacia los modos románticos del otro lado del Atlántico, adonde pertenece por nacimiento, y los adapta a la realidad americana, que ya es la suya por adopción y por convicción. Su romanticismo no es, probablemente, el del llamado "americanismo literario", el de la mitificación de la historia patria y las costumbres vernáculas, ni tampoco el del tono antiespañol (Barrera y Béjar, 1999, pp. 10-17), pero sí es el que busca la expresión de aspiraciones colectivas, políticas y sociales, y sobre todo el que transforma en versos la emoción intensa de una subjetividad potente, rebelde y exuberante.

Pero además, en su calidad de escritora hispanoamericana -nunca aplicado el epíteto con más propiedad-, a la vez española y guatemalteca, la obra de García Granados merece traspasar las fronteras de su país de adopción para constituir un referente y quizá también un nuevo punto de partida para los estudios sobre el sujeto poético femenino en el Romanticismo. Cuando Carolina Coronado, Gertrudis Gómez de Avellaneda, Josefa Massanés y el resto de escritoras románticas estaban realizando sus primeros pinitos líricos al otro lado del océano, en el centro de América ya una mujer había cultivado la sátira política y social, y había sabido verter en sus versos muchos de los motivos que van a ser recurrentes en la producción lírica femenina a partir de mediados de siglo. María Josefa García Granados se había ganado, con todo el derecho, su condición de pionera en la construcción del sujeto femenino en la poesía romántica de uno y otro lado del Atlántico. 


\section{Referencias}

Albizúrez, F., y Barrios, C. (1981). Historia de la literatura guatemalteca. Guatemala: Editorial Universitaria de Guatemala.

Arzú, J. (1940). Pepe Batres íntimo. Guatemala: Tipografía Sánchez \& De Guise.

Ávila, M. A. (2004). Mujer, cuerpo y palabra. Tres décadas de re-creación del sujeto de la poeta guatemalteca. Madrid: Torremozas.

Barreda, P. y Béjar, E. (1999). Poética de la nación. Poesía romántica en Hispanoamérica (crítica y antología). Boulder (Colorado): Society of Spanish and Spanish-American Studies.

Batres Jáuregui, A. (1879). Literatura americana. Guatemala: Imprenta El Progreso.

Brañas, C. (1948). María Josefa García Granados. El Imparcial, julio.

Carilla, E. (1967). El romanticismo en la América hispánica. Madrid: Gredos.

Carrera, M. A. (1984). Los neoclásicos blasfemos, Pepe y Pepita... En Crítica, 133-142. Guatemala: Tipografía Nacional.

De Vallejo, C. V. (1993). Antología de la poesía del Romanticismo hispanoamericano. Miami: Ediciones Universal.

Díaz, V. M. (1932). Los versos de Pepita García Granados. Diario de Centro América, 25 de mayo.

Establier Pérez, H. (2015). Escribir y sentir entre la Península y América: la presencia del Romanticismo español en las poesías guatemaltecas de María Josefa García Granados. En J. Ma Ferri Coll y E. Rubio Cremades (eds.), La tribu liberal. El romanticismo en las dos orillas del Atlántico (201-215). Madrid/Frankfurt am Mein, Iberoamericana/Vervuert.

Figueroa Marroquín, H., y Acuña, A. (1977). Poesía femenina guatemalense. Vol. II. Guatemala: Editorial Universitaria.

Gallegos Valdés, L. (1984). Letras de Centro América. Desde el Popol-Vuh hasta Miguel Ángel Asturias. San Salvador: Ministerio de Educación.

García Granados, M. (1952). Memorias del General Miguel García Granados, Tomos I-IV. Guatemala: Biblioteca de Cultura Popular, Ministerio de Educación Pública.

Grases, P. (1962). Tiempo de Bello en Londres y otros ensayos. Caracas: Ministerio de Educación.

Hoeg, J. (2004). María Josefa Granados: Textos y contextos. En Oralia PrebleNiemi y Luis A. Jiménez (eds.), Ilustres autores guatemaltecos del S. XIX y $X X$ (pp. 23-32). Guatemala: Librerías Artemis Edinter.

Liano, D. (1984). La palabra y el sueño. Literatura y sociedad en Guatemala. Roma: Bulzoni.

López, G. (2009). Antología de poetas guatemaltecas. Guatemala: USAC. 
Manzano Garías, A. (1969). De una década extremeña y romántica. Revista de Estudios Extremeños, 24, 1-29.

Martí, J. (2007) [1913]. Guatemala. Guatemala: Tipografía Nacional. (Biblioteca Virtual Miguel de Cervantes).

Mayoral, M. (1993). Las amistades románticas: un mundo equívoco. En G. Duby y M. Perrot (eds.), Historia de las mujeres en Occidente, El siglo XIX. Vol. IV. (pp. 307-321). Madrid: Taurus.

Mencos Franco, A. (1899-1900). Una poetisa guatemalteca. Diario La República.

Méndez de la Vega, L. (2002). Mujer, desnudez y palabras. Antología de desmitificadoras guatemaltecas. Guatemala: Librerías Artemis Edinter.

Menéndez Pelayo, M. (1948). Historia de la poesía hispanoamericana, I. Santander: Consejo Superior de Investigaciones Científicas.

Montúfar, L. (1898). Memorias autobiográficas. Guatemala: Tipografía Nacional.

Noriega, E. (ed.). (2010). María Josefa García Granados. Su poesía. Guatemala: Tipografía Nacional.

Porta Mencos, H. (ed.). (1928). Parnaso guatemalteco (1750-1928). Guatemala: Tipografía Nacional.

Rivera-Rodas, Ó. (1988). La poesía hispanoamericana del siglo XIX (del romanticismo al modernismo). Madrid: Alhambra.

Salazar, R. A. (1896). El tiempo viejo. Recuerdos de mi juventud. Guatemala: Tipografía Nacional.

Salgado, M. A. (2004). La poesía guatemalteca del siglo XIX a vista de pájaro. En Oralia Preble-Niemi y Luis A. Jiménez (eds.), Ilustres autores guatemaltecos del S. XIX y XX (pp. 67-91). Guatemala: Librerías Artemis Edinter.

Torres Valenzuela, M. A. (1989). Rasgos ideológicos en la producción literaria satírica de María Josefa García Granados. Primeros aportes. Tesis de Graduación, Universidad de San Carlos de Guatemala, Facultad de Humanidades.

Uriarte, R. (2009 [1888]). Galería poética centroamericana. 2a. edición. Guatemala: Tipografía Nacional.

Vela, D. (1943). Literatura guatemalteca. Vol. 2. Guatemala: Unión Tipográfica Muñoz.

Villacorta C., J. L. (ed.) (1971). María Josefa García Granados. Guatemala: Editorial José de Pineda Ibarra.

Wentzlaff-Eggebert, Ch. (1995). Risas y risotadas en la literatura hispanoamericana después de la Independencia. Romanticismo 5. La sonrisa romántica (Sobre lo lúdico del Romanticismo hispánico) (pp. 237-250). Napóles: Bulzoni Editore. 